\title{
Impact of Ownership Structure and Firm Size on the Operational Risk Management of Islamic Banks in Pakistan
}

\author{
ADNAN \\ Management Student, Institute of Business Studies and Leadership \\ Abdul Wali Khan University Mardan \\ Dr. MUHAMMAD IBRAHIM KHAN \\ Assistant Professor, Institute of Business Studies and Leadership \\ Abdul Wali Khan University Mardan, Pakistan \\ DR. SHEHZAD KHAN \\ Assistant Professor, Institute of Business Studies and Leadership \\ Abdul Wali Khan University Mardan, Pakistan \\ SYED IMRAN KHAN \\ Lecturer, Institute of Business Studies and Leadership \\ Abdul Wali Khan University, Mardan \\ syedzadaimran@awkum.edu.pk
}

\begin{abstract}
This study investigates the impact of ownership structure and firm size on the operational risk management (ORM) in the context of Islamic banks in Pakistan. ORM is the excess capital acquired after subtracting actual capital from minimum capital required for handling operational risk. While, the bank size is measured as deposit plus advances or log of total assets. The Basic Indicator Approach (BIA), and Standardize Approach (STA) is used to measure the minimum capital required for managing operational risk. A panel data set of 19 Islamic banks listed on the Pakistan Stock Exchange (PSX) is analyzed over the period from 2012 to 2016.Three important observations are provided by the results; first increase in the size of the Islamic banks tend to lower the surplus capital maintain by banks for managing operational risk. Second, a significant positive relationship is reported between excess capitals required for managing operational risk and public owned Islamic banks. Third, the results are reported as robust as all three regression model provided similar results.
\end{abstract}

Keywords: Capital adequacy standard, Operational Risk, Excess Capital, Capital requirement, Risk Management, Islamic Banks, Size, Ownership.

\section{Introduction}

Over the past two and half decades the operational risk management has received considerable attentions from the firm managers who are trying to measure and alleviate the incurable effects of risk on the financial industry. Financial scandals like bankruptcy, rough trading and internal fraud in this industry in the previous few decades are the results of failure of banking system such as Bank of New York incurred losses of \$140 
million due to internal fraud; Allied Irish losses \$690 million in rough trading (Izhar, 2012; Chernobai et al., 2007); Diawa and the Sumimoto corporation incurred losses of $\$ 2.1$ billion due to unauthorized trading activates (Coleman, 2011). The size of the above-mentioned scandals has increased the complexities in operating Banks (Galloppo \& Rogora, 2011). The need of Operational risk management was first reported in the 1990s which led to the signing of Basel Accord in financial industry and served as a universal mediator for operational risk management in banks to minimize the operational risk (Janakiraman, 2008; Chernobai et al., 2007). The consistent development in ecommerce and technology has effectively improved the operational risk management over the period of time (Buchelt and Unteregger, 2004; Li, 2003). As the banks acts as a financial intermediary in the financial system; their earnings are visible to the creditors, market players and operational risk managers. Therefore, maintaining minimum capital under Basel accord for operational risk control will preserve the financial institution from bankruptcy in case of economic meltdown and will keep the banking system smooth (Gardener \& Ayling, 1984).

Risk management is extensively developed in conventional banking but to less extent to Islamic Banking. Although, the most recent financial crisis (2006-2009) avoided the Islamic banking from meltdown due to its less exclusion from mainstream financial system but also due to its less proportion in total financial transaction. However, the recent growth in Islamic finance related assets which is worth of $\$ 2$ trillion (till 2016), raises the need of streamlining the operational risk management in Islamic Banks (Albawaba, 2017). Islamic banking is more exposed to the operational risk due to greater number of contracts, lack of standardization in Islamic finance practices, newer supporting system (Akkizidis \& Khandelwal, 2008). In this regard, determinants of operational risk management need to be analysed to explore an exhaustive operational risk's management system. Therefore, this study warrants the importance to gauge the influence of ownership structure and firm' size on operational risk management in context of Islamic banks as examined by Sharifi et al. (2016) in case of conventional banks.

\section{Literature Review}

The Basel Committee on Banking Supervision (2003) outlined the diversity of operational risk and specified that "this can happen in any activity and called it as an unwanted product of unprecedented business operation". It means that there could be losses due to operational risk, especially when there is no improvement in return rates on capital and assets. Lewis and Lantsman (2005) regard unilateral operations risk as a unilateral estimate of loss. This means that the bank loses will not affect the other banks. They further categorized the operational risks as unilaterally. According to them, "the risk of loss is not linked to shared market forces." Their research underscores the complexity of changing factors in banks, making it difficult to distinguish characteristics of a lost proportion from this type of risk. Hull (2007) reported that the policymakers of organization give three reasons to maintain excess capital charges for operational risk; first as the bank size increase the working environment will become more complex with greater possibilities of human errors and computer errors (hacking of banking data etc.), second the policymakers want that banks should provide full concentration to their internal system to avoid losses like fraud, bad lending, poorly understood derivatives, 
counterparty failures etc., third the capital requirement for majority of banks will be decreased due to the effects of Basel II credit risk calculation criteria. Thus, emphasizing on the importance of Bank size in the determination of capital required for operational risk management.

Laeven and Levine (2008) reported that as the banks size increases, it pursues complex business activities and their organizational arrangement become more confusing which make agency problem and ultimately enhancing operational risk. However, Shih et al. (2000) study revealed that relationship of size with operational losses is not linear and shows a clear weakening association of the firm' size and the losses magnitude. They reason for weak relationship could be due to factors such as inherent difference in risks, management competence and the effectiveness of internal control management. Likewise, Beck et al. (2013) argue that the small bank as compared to large banks are more exposed to market risk and are likely to uphold additional capital. In comparison, big banks are likely to uphold a small amount of additional capital for operational risk management. The reason is that large banks have advanced internal control mechanism and techniques to manage the operational risk. Large banks benefit from Too big to fail subsidies but due to government involvement, the administrative structure of large banks will be high which results in less operational risk creation in the system, further results that the capital for managing operational risk will be lower (Krugman, 2009).

Moussa (2014) examined 19 banks in Tunisisa between 2000 to 2010 and reported a diminishing association between bank risk and public ownership. In comparison, his study reported a positive influence of non-government (private) and cross border (foreign) ownership on the bank risk. Bank ownership has significant effect on the bank risk due to the different objectives set by private and public shareholders. The reason is that ownership structure influences the decisions of mangers related to risk aversion. It is argued that public ownership bank is less exposed to market risk compared to private owned banks due to their social goals than profit maximizing goals (Teresa and Dolores, 2008). As Laporta et al. (2002) argued that although operational risk reduced due to state guarantee in case of Public owned Banks as evident from the role of European government in injecting capital to the banks in case of recent financial crisis (Ianotta et al., 2012). However, at the same time state rescue of public owned Banks also promote inefficiency in financial system on one hand and political based credit and loans on other hand. Contrary, private banks presence increase competition in the market and reduce barriers results in increase in transaction, but more exposure to risk exchange of securities (Otchere, 2009). Ianotta et al. (2012) disagree and reported that Public owned large banks in Western Europe are more exposed to operational risk than private banks. The reason lied in the state protection of Public banks in case of borrower default.

Srairi (2013) analyzed the impact of ownership structure in both conventional and private banks on the risk-taking behavior in 10 MENA countries. Results reported significant negative influence of ownership concentration on risk. State owned banks have high risk and carry high proportion of non-performing loans. Contrary, private owned Islamic and conventional banks are more stable. Sharifi et al. (2016) reported that the Indian government banks hold surplus capital for risk than private owned banks because these banks have state ownership and the interfering from public officials and administrators in case bad loan. It means that the loan managers are more conservatives in loan decision 
because their decision is likely to be questioned or investigated by government agencies at any time in future. In light of the review of above literature, this study expects a negative relationship of banks size and ownership structure with the excess capital maintained by the bank to manage operational risk.

H1: The Islamic bank's size negatively influences the excess capital detained for the operational risk management.

$H_{2}$ : There is a positive association between private owned banks and the additional capital maintain by the bank to manage operational risk.

\section{Research Methodology}

\subsection{Data}

This study used secondary data taken from the Islamic Bank's annual report operating in Pakistan. In total a sample of 21 banks are filtered based on Islamic banking provision but due to unavailability of data the sample size decrease to 19 . The sample banks are then segregated on the basis of their ownership structure such as 5 private and 3 government banks wholly operate in Islamic finance while 11 private banks operate in both conventional and Islamic finance. The data for the selected sample is acquired over the period from Dec 2012 to Dec 2016. The data is panel in nature as it is across the time period and across the firms.

\subsection{Variable Construction}

The objective of the study is to examine the impact of size and ownership structure on the excess capital set for managing the operational risk in the Islamic Bank of Pakistan. To achieve the purpose, the study employed a number of variables such as level of capital reserve for operational risk management, firm size, ownership structure and leverage which are measured as below;

\subsubsection{Dependent Variables}

The excess of capital is obtained as the actual capital held by banks minus the minimum capital required for operational risk management. The study employed basic indicator approach for the estimation of minimum capital required as recommended under Basel II standards (Abdullah, 2007). While, gross income is obtained from the annual financial reports of the banks. The observations are calculated in log form to ensure normality in the date and is numerically expressed as below;

$$
L E C G I_{i, t}=\log \left(\frac{\text { Excess capital }}{\text { Gross income }}\right.
$$

Where

LECGI stand for log of excess capital to gross incomes set for operational risk management. Excess Capital $(\mathrm{EC})=$ Actual Capital for operational risk management minus minimum Capital required. Minimum Capital is equal to fifteen percent of average positive gross income of preceding 3 years (Abdullah et al., 2007). Where gross income is the net income from service-based activities plus net trading income from the Murabahah, salaam, and Ijara based transactions plus other income such as investments in Shari'a-compliant securities, including Sukuk, and Mudarabah and Musharakah based investments (Iqbal \& Mirakhor, 2007). 


\subsubsection{Independent Variables}

Following variables are identified from the literature review as the potential determinants of the capital set for operational risk management in line with previous study of Sharifi et al. (2016).

\subsubsection{Bank Size}

Bank size is selected as the independent variable. A number of studies have used log of assets or log of sale as a proxy for firm size (Shih et al., 2000; Harford, 1999). However, in case of banks, assets are usually comprised of deposits and advances made in the form of loan. In line of that, the study employed log of deposit plus advance as proxy for bank size (Sharifi et al., 2016).

$$
\begin{aligned}
\text { LSIZE }=\log \text { of } & (\text { Deposits } \\
& + \text { Advances })
\end{aligned}
$$

\subsubsection{Ownership Structure}

This study shortlisted a sample of 19 Islamic banks operating in Pakistan over the period from 2012 to 2016. Due to the unavailability of the exact proportion of ownership holding in the sample Banks, the study used dummy variable as proxy for ownership structure (as used by Rao, 2016). Such as the government owned bank is denoted by "1" while the private owned bank is denoted by " 0 ".

\subsubsection{Control Variable}

\subsubsection{Leverage}

The study used leverage as a control variable which is defined as total debts divide by equity (Mengesha, 2014). Numerically it is expressed as below;

$$
\text { Leverage }=\frac{\text { Total Debts }}{\text { Total Equity }}
$$

\subsection{Regression Model}

The panel regression model is used to explore the relationship between dependent and independent variables. For the robustness of the result, the study used Pooled OLS, Fixed effect, and Random effect models. The equation 5 explained the regression estimation between dependent and independent variables based on Pooled OLS, Fixed and Random effect models.

$$
\operatorname{LECGI}_{i, t}=\beta_{0}+\beta_{1} \operatorname{LSize}_{i, t}+\beta_{2} \text { Ownt }_{i, t}+\beta_{3} L L e v_{i, t}+\mu_{i, t}
$$

Where, $\mathrm{ECGI}_{\mathrm{i}, \mathrm{t}}$ is $\log$ of the excess capital for operational risk management for bank ' $\mathrm{i}$ ' at period ' $t$ ', LSize ${ }_{i, t}$ is log of the Size for bank ' $i$ ' at period' $t$ ', Ownt ${ }_{i, t}$ is the ownership dummy for bank ' $i$ ' at periods', $\operatorname{LLev}_{\mathrm{i}, \mathrm{t}}$ is the $\log$ of leverages for bank ' $\mathrm{i}$ ' at period' $\mathrm{t}$ ', $\mu$ $(\mathrm{i}, \mathrm{t})$ is Random error term

\section{Empirical Results}

\subsection{Descriptive Statistics}

Below table 1 illustrate the statistical description of the variables used in the regression model. It can be observed from the below table that LECGI under basic indicator approach has a mean value of 6.977 , the maximum value of 11.47 , the minimum value of 3.813 , which mean that the average value of the excess of capital lies between 11.47 and 
3.813. While the LSIZE is the log of the assets of the banks have the mean value 2.019 with minimum value 1.784 and maximum value 2.176 . The control variable LLev has a mean value of 2.515 with minimum value -0.255 and the maximum value of 3.903 . Ownt stand for the ownership of Banks with a mean value of 0.157. All values of Ownt lies between minimum value of 0.000 and the maximum value of 1.000 due to the dummy values undertaken. Among variables mentioned in table 1, high variation is reported for the variable of LECGI with the standard deviation of 1.798. This suggest that there is the high difference in excess of capital to gross income among sample banks and is also confirmed from difference between Min and Max values.

\section{Table 1: Descriptive Statistics}

\begin{tabular}{lcccc}
\hline & LECGI & LSIZE & LLEV & OWNT \\
\hline Mean & 6.97 & 2.01 & 2.51 & 0.15 \\
Median & 7.11 & 2.02 & 2.58 & 0.00 \\
Maximum & 11.4 & 2.17 & 3.90 & 1.00 \\
Minimum & 3.81 & 1.78 & -0.25 & 0.00 \\
Std. Dev. & 1.79 & 0.07 & 0.70 & 0.36 \\
\hline
\end{tabular}

Note: LEKGI: $\log$ of an excess of capital to gross income is the proxy for operational risk management. LSIZE represent the log of deposit plus advances and LLEV represents the log of leverage, OWNT represent dummy variable for ownership structure. P represent the probability for the normality test.

\subsection{Regression Estimates}

Results depicted in table 2 that under Basic Indicator Approach, the constant $\mathrm{C}$ is found with a positive coefficient value of 26.1 with a p-value of less than 0.05 . Thus, suggesting that $\mathrm{C}$ is significant and if there is no independent variable or if the independent variable is zero then the value of a dependent variable which is LECGI, would be 26.1. While the constant $\mathrm{C}$ value in Random effect model is positive coefficient value 18.8 with a $p$-value of 0.000 which is less than $5 \%$ also suggests that $\mathrm{C}$ is significant. It can also be observed from the table 2 that Bank size is significantly negatively related to LECGI in all models (i.e. Pooled OLS, Fixed effect, and Random effect). This means that the large is the size of Islamic bank the lower would be the excess capital held by the bank. The impact of Islamic bank' size on the LECGI is similar to the conventional bank as reported by Sharifi et al. (2016). Therefore, the study accepts the main hypothesis that is the bank size has significant power to explain the excess capital held by Bank for operational risk management. Likewise, government owned banks have reported significant positive association with additional capital detained for handling the operational risk. The reason could be that government owned banks hold the public confidence and in case of default could jeopardize the public trust on whole financial system of the country. Apart being a state property, such banks are under more scrutiny from regulatory authorities in case of default. Thus the study reject the second main hypothesis which state that private owned banks have positive association with excess capital held for operational risk management in Islamic banks (in line with the findings of Sharifi et al., 2016). Moreover, as per expectation insignificant but negative association is reported between leverage and LECGI. Thus, suggest that leverage has limited role in estimation of excess capital held for operational risk management. Table 2 also illustrate that under Hausman test the study 
preferred fixed effect model over random effect mode. However, after examining the results obtained through all three models presented in table 2 , it can be concluded that results are robust in nature and are not sensitive to the type of model undertaken.

Table 2: Fixed, Random and OLS Results under Basic Indicator Approach

\begin{tabular}{|c|c|c|c|c|c|c|}
\hline Variables & Fixed & & $\begin{array}{l}\text { Randor } \\
\text { effect }\end{array}$ & & Pooled & $\mathbf{L S}$ \\
\hline & Coefficient & Prob & Coefficient & Prob & Coefficient & Prob \\
\hline $\mathrm{C}$ & 26.11 & 0.00 & 18.86 & 0.00 & 37.62 & 0.00 \\
\hline Lsize & -9.36 & 0.01 & -5.74 & 0.01 & -15.65 & 0.00 \\
\hline LLve & -0.08 & 0.53 & -0.16 & 0.11 & -0.39 & 0.14 \\
\hline Ownt & 0.11 & 0.01 & 0.75 & 0.00 & 0.08 & 0.00 \\
\hline $\mathrm{R}^{2}$ & 0.38 & & 0.42 & & 0.58 & \\
\hline Adj $R^{2}$ & 0.32 & & 0.39 & & 0.52 & \\
\hline F-stat & 197 & & 13.10 & & 44.78 & \\
\hline $\operatorname{Prob}(F-s t a t)$ & 0.00 & & 0.00 & & 0.00 & \\
\hline Durbin-Watson & 2.88 & & 1.57 & & 1.94 & \\
\hline Correlated Random & 0.00 & & - & & - & \\
\hline Effects - Hausman & & & & & & \\
\hline & & & & & & \\
\hline p-value & & & & & & \\
\hline
\end{tabular}

The table presents the regression result based on Basic Indicator Approach including fixed effect, random effect and Polled OLS. Prob represent probability at a significant value of 0.05 .

\subsubsection{Test for Serial Correlation}

The serial correlation test under the Basic Indicator Approach in the Regression model for calculating the serial correlation we used Breusch-Godfrey Serial Correlation LM Test. On the basis of prob value, we estimate that whether the model is serial correlated or not the result shows the chi-square value is less than $5 \%$ meaning that there is a positive and first-order autocorrelation exists in our model. With the help of AR (1) remove autocorrelation we used first-order autocorrelation model after estimate the equation the $\mathrm{F}$ statics value is 0.1398 and it's probability $\mathrm{F} 0.86$ while the value of observed R square 0.3178 and its Prob Chi-Square 0.85. So in our model, the P value is more than $5 \%$ that is 0.5426 , so we can say that the data is free of serial correlation problem among the variables. Now, this model is a dynamic model, not a static model because the dependent variable values show into lag.

\subsubsection{Test for Heteroscedasticity}

we also calculate the heteroscedasticity problem under Basic Indicator Approach whether heteroscedasticity exist or not in our model, with the help of Heteroskedasticity Test Breusch-Pagan-Godfrey result show that the observe R square value is 1.74 and its Prob is 0.62 reflecting no Heteroscedasticity problem in the model because the Prob value is more than $5 \%$. So, this model is good because there is no heteroscedasticity.

\section{Conclusion}

This study found that with the increase in the size of the Islamic banks in Pakistan tend to lower the surplus capital maintain by them for handling operational risk. The negative 
association between Islamic bank' size and ORM means that small size Islamic banks maintain higher excess capital against the minimum required capital as suggested in Basel II accord. The rational is that smaller banks did not have a strong sophisticated internal control system and managerial skills so there are more chances of higher operational losses events has to occurs. In comparison, big banks tend to have sophisticated internal system with managerial expertise, exposing it less to operational risk. The study further found a significant positive relationship between excess capitals required for managing operational risk and state based ownership structure of Islamic banks. Thus, suggest that the state-owned Islamic banks maintain high level of additional capital for controlling operational risk management than private owned Islamic banks. In other words, state owned banks have better ORM practices than private owned banks.

\section{References}

Abdullah, M., Shahimi, S., \& Ismail, A. (2011). Operational risk in Islamic Banks: Examination of Issues. Qualitative Research in Financial Markets, 3(2), 131151.

Albawaba (2017). Islamic financ gorwth slow down 2018 report. Access from https://www.albawaba.com/business/islamic-finance-growth-slow-down-2018report-989100

Akkizidis, I. S. \& Khandelwal, S. K. (2008).Financial Risk Management for Islamic Banking and Finance. New York: Palgrave MacMillan.

Beck, T., Asli, D., \& Ouadra, M. (2010). Islamic vs. Conventional Banking: Business Model, Efficiency, and Stability. Policy Research Working Paper

Buchelt, R. and Unteregger, S. (2004). Cultural risk and risk culture: operational risk after Basel II. Financial Stability Report 6. Access from http://www.oenb.at/en/img/fsr_06_cultural_risk_tcm16-9495.pdf.

Basel Committee on Banking Supervision, (2001). Operational Risk, consultative document, Basel: Bank for International Settlements

Chernobai, A., Rachev, S. T. and Fabozzi, F. J. (2007). Operational Risk: A Guide to Basel II Capital Requirements, Models, and Analysis. John Wiley \& Sons

Galloppo, G., \& Rogoro, A. (2011). What has worked in operation risk? Global Journal of Business Research, 5(3), 1-17

Gardener, E., \& Ayling, D. (1984). Operational approaches to risk management in financial institutions: A technique for commercial banks. Managerial Finance, 10(1), 15-19

Harford, J. (1999). Corporate cash reserves and acquisitions. Journal of Finance, 54, 1969-1997

Hull, J. (2012). Risk management and financial institutions ( $3^{\text {rd }}$ ed.). Willey Finance.

Iannotta, G., Nocera, G., \& Sironi, A. (2012). The impact of government ownership on bank risk. www.unibocconi.eu, 1-40

Iqbal, Z., \& Mirakhor, A. (2007). An Introduction to Islamic Finance: Theory and Practice

Izhar, H. (2012). Measuring Operational Risk Exposure in Islamic Banking: A proposed Measurement Approach. Islamic Economic Studies, 20(1) 
Janakiraman, U. (2008). Operational risk management in Indian banks in the context of Basel II: A survey of state of preparedness and challenges in developing the framework. Asia Pacific Journal of Finance and Banking Research, 2(2)

Krugman, P. (2009, June 18). Too big to fail. New York Times

Laeven, L., \& Levine, R. (2008). Banking governance, regulation and risk taking. Journal of Financial Economics, 93, 259-275

Laporta .R, Lopez-de-Silanes .F, \& Shleifer .A. (2002). Government ownership of banks. Journal of Finance, 57(1), 265-301

Lewis, M., \& Lantsman, Y. (2005). What is a fair price to transfer the risk of unauthorized trading? A case study on operational risk, operational risk: Practical approaches to implementation. London: Risk Books, 315-356

Mangesha, W. (2014). Impact of working capital management on firms' performance: The case of selected metal manufacturing companies in Addis Ababa, Ethiopia. Thesis, Jimma University, Jimma.

Moussa, M. (2014). The impact of ownership structure on bank risk: case of Tunisia. Developing Country Studies, 4(4)

Otchere .I. (2009). Competitive and value effects of bank privatization in developed countries. Journal of Banking and Finance, 33, 2373-2385

Shih, J., Samad-Khan, A., \& Medapa, P. (2000). Is the size of an operational loss related to firm size? Operational Risk. Access from URL http://www.stamfordrisk.com/docs/Is_the_Size_of_an_Operational_Loss_Relate d_to_Firm_Size_(Jan_00).pdf

Sharifi, S., Haldar, A., \& Rao, S. N. (2016). Relationship between operational risk management, Size, and ownership of Indian Banks. Managerial Finance, 42(10), 930-942.

Srairi, S. (2013). Ownership structure and risk-taking behavior in conventional and Islamic banks: evidence for MENA countries. Borsa Istanbul Review, 13(4), 115127

Teresa, G. M., \& Dolores, R. F. (2008). Risk-taking behavior and ownership in the banking industry: the Spanish evidence. Journal of Economics and Business, 60(4), 332-354 